Encouraging Innovation in Business Relationships-A Research Note

March 2011

Erik A. Mooi - Corresponding author

VU University Amsterdam - Marketing Department

De Boelelaan 1105, 1081HV Amsterdam, the Netherlands

Email: emooi@feweb.vu.nl

Tel: $\quad+31205982565$

Ruud T. Frambach

VU University Amsterdam

Email: rframbach@feweb.vu.nl

Tel: $\quad+31205987145$ 


\title{
Encouraging Innovation in Business Relationships-A Research Note
}

\begin{abstract}
How do buyer-supplier relationships affect innovation? This study suggests that the relational exchange norms flexibility, information sharing, and solidarity (the bright side) encourage buyer innovation. However, negative (dark side) aspects of relationships with suppliers - loss of supplier objectivity, increasing buyer expectations, and supplier opportunism - may accompany the bright side and subsequently reduce buyer innovation. The study reports on the simultaneous effects of the bright and dark sides on innovation and the resultant effect on supplier performance as evaluated from the buyer's perspective. Using data from the travel and computer industry, regression models reveal that the bright side encourages buyer innovation. Buyers reciprocate this support by enhancing their supplier evaluations. The findings indicate that rising buyer expectations - supposedly a dark side of relational exchange - encourage innovation, while loss of supplier objectivity reduces relationship performance. These findings imply that the bright and dark sides are not mutually exclusive dimensions of good versus bad behavior.
\end{abstract}

KEYWORDS: innovation, relational exchange norms, dark side, opportunism 


\section{Introduction}

Observation from practice suggests that building relationships helps innovation. For example, von Hippel (1988) finds that in certain industries most innovations originate from suppliers' ideas and suggestions. How buyer-supplier relationships actually encourage buyer innovation has received little attention. This is surprising, as innovation is a valuable benefit for the buyer, going beyond prices and products. Following Strutton, Pelton, and Lumpkin's definition (1993), innovation is the encouragement of improvement by the supplier with regard to how the buyer solves problems, develops ideas, and thinks of (process) improvements. For example, in the travel industry, several airlines, hotels, and car rental companies have encouraged travel agents to develop innovations, such as dynamic packaging, which expedite new travel package creation (http://www.ettsa.eu).

Innovation is important to buyers, as greater innovation helps them adapt to changing environments and develop competitive advantages (Hurley and Hult, 1998). The present study demonstrates that when suppliers encourage buyer innovation, the buyer reciprocates this support by evaluating the relationship with the supplier more positively. This reciprocity suggests a route that suppliers could take to increase their buyer ratings and to strengthen their position.

This study links innovation to relational exchange norms, defined as shared expectations about supplier behavior (Heide and John, 1992). These relational exchange norms, labeled the bright side, complement potentially negative aspects of relationships (the dark side). This dark side consists of rising buyer expectations, loss of supplier objectivity, and supplier opportunism (Grayson and Ambler, 1999). Dark side variables are complements to norms, but not norms themselves as they are not necessarily shared expectations. Different from previous research, this 
paper investigates if relational exchange norms and the dark side represent mutually exclusive dimensions of good versus bad behavior within relationships as some argue for, or if the dark side is also present in relationships where relational exchange norms are well developed (Heide and John 1992).

\section{Theoretical Development}

This study takes the perspective of the buyer in a vertical exchange relationship with its supplier. The buyer reports on its relationship with this supplier, how the supplier encourages innovation, and how the supplier performs within the relationship. The study draws upon the relational exchange literature, which forms the basis for scholars' study of exchanges between firms (Noordewier, John, and Nevin, 1990; Heide and John, 1992; Lusch and Brown, 1996). Adding a dark side allows to take a balanced perspective towards relational exchange norms, as there is evidence that if relational exchange norms are present to a high degree, performance may suffer (Grayson and Ambler, 1999). This study therefore includes the direct effects of the dark side on relationship performance, as the dashed line in Figure 1 indicates. Relational exchange norms and dark side perspectives thus subsequently explain innovation and supplier performance (as rated by the buyer). Including supplier performance helps determine if the buyer reciprocates the supplier encouraging innovation. The key to the proposed model (see Figure 1) is the expectation that relational exchange norms encourage buyer innovation while the dark side factors discourage this innovation. Moreover, the model suggests that relational exchange norms do not directly affect performance, but that relationship performance increases if these exchange norms provide a benefit to buyers through innovation (i.e., a mediating model). This study uses the innovation literature to establish innovation as a critical mediator that enhances performance (Strutton, Pelton, and Lumpkin, 1993; Hurley and Hult, 1998). 
Figure 1 about here

The influence of the bright side on innovation

The bright side norms comprise flexibility, information exchange, and solidarity (Lusch and Brown, 1996; Jap and Ganesan, 2000; Bercovitz, Jap, and Nickerson, 2006). Flexibility in relationships is the expectancy that parties are willing to make adjustments according to changing circumstances (Heide and John, 1992). If flexibility is present, parties can learn from past successes and can create the culture to be innovative (Hurley and Hult, 1998). Previous research has suggested that flexibility reflects innovation (Strutton, Pelton, and Lumpkin, 1993). However, parties' willingness to make adjustments within a relationship (i.e., display flexibility) is a prerequisite, but not a motive for innovation. This suggests that flexibility and innovation are distinct variables. Information exchange is the free exchange of information, even if the party providing information does not benefit directly. Information exchange can increase the creativity to develop new products or services (Moorman and Miner, 1997), because collaboration provides access to suggestions for improvement, information, and resources that a firm cannot generate internally. In addition, information exchange facilitates learning, which is an important antecedent of innovation (Hurley and Hult, 1998). Finally, solidarity refers to a norm with which to jointly solve individual and common problems (Lusch and Brown, 1996). Solidarity increases one party's interest in the welfare of the other and promotes a long-term orientation (Bercovitz, Jap, and Nickerson, 2006). Suggesting potential innovations is a way of expressing concern for the other party's welfare. Solidarity also reduces conflict, thereby stimulating a climate in which suppliers can suggest improvements rather than resorting to politicizing or bargaining. 
This study suggests that, through innovation, the bright side of relationships impacts relationship performance indirectly. This suggestion reflects the notion that exchange norms are not of immediate value per se, but that the way in which they impact how buyers innovate (and sellers encourage them to do so) allow these norms to enhance performance. The logic behind this is that, ceteris paribus, developing relational exchange norms carries costs that reduce performance. Only if these relational exchange norms allow buyers and suppliers to deal more effectively with the environment through innovation, are relational exchange norms' advantages likely to outweigh the costs of developing the norms. Therefore:

H1: The higher the level of (a) flexibility, (b) information exchange, and (c) solidarity in a buyer-supplier relationship, the more the supplier encourages the buyer to innovate.

The influence of the dark side on innovation

Williamson (1975) suggested many years ago that a dark side consisting of opportunism is present in relationships. Nevertheless, subsequent research on buyer-supplier relationships mostly ignored the dark side. More recent work by Grayson and Ambler (1999) expanded the dark side concept beyond opportunism to include increasing buyer expectations and the loss of supplier objectivity. Collectively, these authors refer to these mentioned issues as relationships' dark side. These dark side aspects could reduce innovation because they diminish exchange partners' involvement and interaction, which are key to encouraging innovation (Grayson and Ambler, 1999).

Rising buyer expectations mean that, in the dynamics of a relationship, buyers increase the standards to which they hold the products and services provided by the supplier. Gruen, 
Summers, and Acito (2000) suggest that as relationships progress, buyers become focused on short-term outcomes and start to expect more from the supplier. Doyle, Korstjens, and Mitchell (1980) and Mitchell and Sanders (1995) ascertain that, over a long time span, suppliers have difficulty offering buyers innovations that meet their demands. As relationships develop, buyers that hold suppliers to increasingly higher standards may become problematic. Increasing expectations among buyers will, ceteris paribus, reduce satisfaction with a relationship with the supplier because of a greater discrepancy between the products and services offered and the buyer's expectations. Because dissatisfaction may result when the supplier does not meet the buyers' expectations, suppliers may refrain from encouraging buyers to innovate as this complicates meeting expectations. Moreover, when an exchange partner becomes less satisfied with the relationship, conflict increases and trust erodes (Geyskens and Steenkamp, 1999). These conditions likely reduce innovation. Reductions in trust also lead to fewer investments in the relationship (Bensaou and Anderson, 1999) that are necessary to redevelop the relationship through innovation. Hence:

H2: The higher the buyer's expectation regarding its supplier, the less the supplier encourages the buyer to innovate.

Loss of supplier objectivity occurs when suppliers become stale and do not adapt to the perspectives of buyers sufficiently (Moorman, Zaltman, and Deshpande, 1992; Grayson and Ambler, 1999). Thus, rather than suppliers relating to buyers' needs, they continue to offer the same services as they had in the past. Firms that do not relate well to buyers' needs are less market oriented. In turn, a lower market orientation decreases innovation (Han, Kim, and 
Srivastava, 1998), because less interfunctional coordination (key to market orientation) reduces creativity and risk taking, while less focus on competitors decreases suppliers' desire to introduce distinct innovations on the market, and less focus on buyers means being less aware of changing needs. Moreover, in relationships characterized by a feeling that the supplier cannot be objective, the buyer may want to terminate the relationship (Mitchell and Sanders, 1995). Suppliers could stop encouraging relationship when they expect that the buyer may terminate the relationship. Thus:

H3: The more the buyer perceives a supplier's loss of objectivity, the less the buyer feels encouraged to innovate.

Supplier opportunism is a negative aspect arising in relationships (Heide, Wathne, and Rokkan, 2007). Much of the previous research has focused on how opportunism creates trading difficulties (Wathne and Heide, 2000). This opportunism is self-interest seeking with guile (Williamson, 1975), with guile defined as taking advantage of opportunities with little regard for principles or consequences. Generally, scholars believe that opportunism has a negative impact on buyers (Hawkins, Wittmann, and Beyerlein, 2008) and that this negativity manifests itself through shirking or evading obligations (Wathne and Heide, 2000). If opportunism is present, buyers or suppliers will hold back from the relationship, reducing the openness required to encourage innovation. Specifically, when supplier opportunism concerns emerge, buyers become less willing to invest in relationships, thus undermining buyer innovation (Wathne and Heide, 2000). Moreover, opportunism may also encompass a refusal to adapt to new circumstances, suggesting a decrease in innovation (Wathne and Heide, 2000). Hence: 
H4: The higher the level of supplier opportunism in a buyer-supplier relationship, the less the buyer feels encouraged to innovate.

\section{Innovation and Relationship Performance}

This study adopts a broad conceptualization of innovation that focuses on encouraging improvement by finding new ways to do things. This type of innovation should enhance relationship performance because the ability to improve allows relationships to redevelop and adjust to changing circumstances (Han, Kim, and Srivastava, 1998). Innovation allows firms to get rid of old work processes and replace them with more effective and efficient processes. The population ecology literature therefore suggests that firms that adapt to their environments have a higher survival rate. Previous research also suggests a robust relationship between innovation and performance (Han, Kim, and Srivastava, 1998). Therefore:

H5: Innovation improves how buyers evaluate relationship performance with their suppliers.

\section{Research Method}

\section{Context}

The empirical context comprises travel agents and tour operators (SIC codes 4724 and 4725 ) and firms active in computer production and wholesaling (SIC codes 5045 and 3571) in the Netherlands. The first industry provides mostly services and the second mostly goods. Table 2 shows the sample's descriptive statistics. 
The data are collected by drawing all addresses in the mentioned industries from the Chamber of Commerce database, which includes all economically active firms. This resulted in a sampling frame of 458 travel agents and tour operators and 325 firms in the computer production and wholesaling sector. The researchers contacted all firms and asked them to participate, provide details of a key informant, and to provide up-to-date contact information.

\section{Data Collecting Procedure}

Based on interviews conducted prior to the survey, the director/CEO appeared to be the most suitable small company informant, and the marketing or sales manager the most suitable large company informant. This paper adopted the suggestions of Kumar, Stern, and Anderson (1993) to check the global and specific informant competency.

The informants filled out a series of questions, keeping a relationship in mind that is important to them. They therefore report on relationships that are salient to the buyers, likely increasing the measures' validity. For travel agents, these relationships are with key suppliers such as airlines (e.g., Air France-KLM) and hotel chains (e.g., Marriott). For the computer production and wholesale sector, the relationships are with memory suppliers (e.g., Kingston) and peripheral suppliers (e.g., Logitech).

Data are collected using mail surveys and adopting Dillman's (2000) procedure. 207 usable responses were received (travel sector: $\mathrm{n}=113,25 \%$ response rate; computer sector: $\mathrm{n}=94$; $29 \%$ response rate).

Nonresponse bias was assessed by testing if the surveyed industries' populations differ significantly from the sample. No significant differences were found between the sample and population, leading to the conclusion that the sample is representative of the population. 


\section{Measurement}

Table 1 provides an overview of all the measurement items, as well as the Cronbach Alpha for reflective constructs with three or more items. Table 2 includes the correlations and summary statistics related to the constructs discussed below.

Table 1 here

Table 2 here

\section{Endogenous variables:}

Relationship performance: is measured on the basis of Kumar, Stern, and Achrol (1992). The adopted scale measures the evaluation of supplier performance from the buyer's perspective. This supplier performance is relative to expectations and how successful the association with the supplier has been. Kumar, Stern, and Achrol (1992) demonstrate that this measure is highly correlated with financial performance and is well suited to compare performance across different firms. Many studies on relationships use this global measure as a dependent variable (e.g., Jap and Ganesan, 2000; Jap and Anderson, 2003), thus allowing comparisons.

Innovation: is the supplier's encouragement of improvement regarding how the buyer solves problems, develops ideas, and thinks of (process) improvements. The measure builds on the one that Strutton, Pelton, and Lumpkin (1993) developed. This broad innovation measure focuses on the organizational challenge to find better work methods, and therefore differs from innovation measures that focus on new product adoption (Hauser, Tellis, and Griffin, 2006). Furthermore, the definition is not restricted to technological change but includes new administrative, operative, and management ideas or processes. This definition of innovation 
works well when used in different contexts, as is the case here. Introducing distinct new products on the market is particularly rare in the travel industry, but there are frequently improvements in the process of making services available. Note that the adopted definition does not imply the innovation to be absolutely novel, only novel relative to the organization (i.e., the buyer).

Exogenous variables:

Flexibility, information exchange, and solidarity: The scales used to measure flexibility, information exchange, and solidarity originate from Heide and John (1992) and Lusch and Brown (1996). This measure taps into the degree to which the buyer perceives shared norms in the buyer-supplier relationship.

Rising buyer expectations, loss of objectivity, and opportunism: Rising buyer expectations are increasing standards of the buyer with regard to the products/services provided by the supplier. Loss of objectivity refers to suppliers that keep offering similar services and products, regardless of changing buyer needs. Opportunism is defined as interest seeking with guile (Williamson, 1975). All dark side measures originate from Grayson and Ambler (1999).

\section{Validation of Measures}

A confirmatory factor analysis assessed the indicators' fit with the constructs studied. The model fit is adequate. The $\chi^{2}$ value obtained is 405.66 at 231 degrees of freedom $(p<.01)$. The comparative fit index is .97 , and the RMSEA is .06.

Consistent with theoretical expectations, the correlations of the latent bright side constructs are high, although these correlations are substantially below unity, which supports the discriminant validity of the bright side factors. The Fornell-Larcker test (1981) ascertained the discriminant validity by comparing the variance extracted from each pair of constructs (with the exception of the formative opportunism construct) to the two constructs' squared correlation. 
Since the variance extracted exceeded the squared correlation of the constructs in every case, the results indicate discriminant validity. Table 2 shows the average variances extracted on the diagonal.

The calculated Cronbach's Alpha coefficients range from .71 to .91. Loss of objectivity has two items correlated -.44. Rising expectations has two items correlated .52. Finally, Harman's one factor test suggests that common method bias is not a problem.

\section{Results}

This study uses ordinary least squares to estimate the regression models. Both models are significant. The model explaining innovation has an $\mathrm{R}^{2}$ of .37 , while the model explaining relationship performance has an $\mathrm{R}^{2}$ of .29 . Table 3 includes details on the model fit and the significance of the various parameters.

Table 3 here

Model 1 in Table 3 suggests that relational exchange norms enhance innovation. More specifically, flexibility, information exchange, and solidarity positively relate to innovation $(\mathrm{T}=2.98,2.14$, and 4.32 respectively). These results support Hypotheses $1 \mathrm{a}, 1 \mathrm{~b}$, and $1 \mathrm{c}$.

With regard to the dark side variables, the findings are mixed. Hypothesis 2 is not supported, and the findings indicate that rising buyer expectations enhance, rather than reduce, innovation $(\mathrm{B}=.13, \mathrm{~T}=2.20)$. Hypothesis 3 states that a loss of objectivity reduces innovation, but the findings suggest no significant link $(\mathrm{B}=-.07, \mathrm{~T}=-1.18)$. Loss of objectivity, however, does reduce relationship performance $(\mathrm{B}=-.28, \mathrm{~T}=-4.90)$. Hypothesis 4 states a negative association 
between opportunism and innovation. The model rejects this hypothesis $(\mathrm{B}=-.01, \mathrm{~T}=-.15)$ but supports Hypothesis 5 , which states that innovation increases relationship performance $(\mathrm{B}=.34$, $\mathrm{T}=5.52)$.

This study follows Baron and Kenny (1986) to test for mediating effects. The findings suggest that innovation partially mediates information exchange and solidarity's effects on relationship performance. Innovation fully mediates flexibility's effect on relationship performance. The percentage of effects mediated is $50 \%, 48 \%$, and $64 \%$ respectively. For completeness, this study tests for possible mediating effects between the dark side constructs and relationship performance. The findings support innovation fully mediating the effect of increasing buyer expectations (60\%), but establish only partial mediation for loss of objectivity $(24 \%)$.

\section{Discussion}

The objective of this study is to investigate how the relationship between buyers and suppliers affect the extent to which suppliers encourage buyers to innovate, and how this subsequently affects buyers' perception of the relationship performance. The findings indicate that innovation has a mediating effect between the bright side of relations and relationship performance. This novel finding suggests that suppliers investing in building relationship norms with their buyers may see this reciprocated by their buyers' better performance evaluations because these buyers feel encouraged to innovate. Including innovation as a mediator may also explain why previous studies exploring the impact of relational exchange norms on relationship performance obtained mixed results.

Owing to enhanced innovation, developing relational norms appears positive to both buyers and suppliers (as suppliers' evaluations by buyers becomes more positive), but a dark side 
complements relational norms. This study presents novel findings on their effect in relation to previously established positive effects of relationship bright side factors on relationship performance. In particular, loss of objectivity among suppliers in a relationship reduces their buyers' evaluation of relationship performance. Surprisingly, loss of objectivity seems to have no effect on innovation but only on performance. An explanation could be that a loss of objectivity causes a misfit between needs and wants, which does not affect the encouragement of innovation, but does affect how the resulting innovations align with the needs.

Interestingly, buyer expectations appear to encourage rather than reduce innovation. One possible explanation may be that if a buyer expects more of a supplier over time, the supplier needs to encourage innovation or face losing a relationship. This suggests that increasing expectations may not be the dark side construct as previously assumed.

There seems to be no significant relationship between opportunism, innovation, and relationship performance. A possible explanation is that the presence of relational exchange norms reduces opportunism (the correlations in Table 2 appear to support this) and that opportunism is an exception in the presence of relatively high relational exchange norms (Heide and John, 1992). Additionally, Joshi and Arnold (1997) argue that, in dependent relationships, the presence of relational norms reduces opportunism.

Previous studies suggest that in longer lasting relationships, dark side aspects are less important because the parties terminate non-functioning relationships (Dwyer, Schurr, and Oh, 1987). The findings from this paper suggest differently. Firstly, empirically, the bright and dark side variables appear to be present in similar levels in shorter and longer lasting relationships. Secondly, loss of objectivity appears to have a highly significant effect on relationship performance, suggesting that this dark side effect continues to exist in relationships and affect 
relationship performance. These findings imply that relational exchange norms and the dark side coexist rather than representing mutually exclusive dimensions of good versus bad behavior as suggested previously (Heide and John, 1992).

\section{Managerial Implications}

This study suggests that suppliers that encourage their buyers to innovate reap the benefits of doing so through an enhanced buyer evaluation of their relationship. This understanding thus adds to previous research on the performance implications of buyer-supplier relationships by showing that there is a payoff for suppliers if they encourage buyers to innovate. Suppliers can encourage innovation by exchanging information with buyers, even if this does not directly benefit suppliers. The supplier's encouragement sends the buyer a signal that its supplier has the relationship's interest in mind. Furthermore, showing the other party that any problem arising in the relationship is a joint problem, and that the responsibility for the relationship's success lies with both parties, stimulates innovation due to enhanced solidarity. Flexibility increases if the parties respond to the requests for changes in the relationship, which also benefits innovation.

The finding that a dark side complements information exchange, solidarity, and flexibility has several implications for suppliers. A loss of supplier objectivity reduces buyer evaluations and implies that suppliers need to stay alert, offering products and services that relate to buyers' needs, rather than providing products and services that buyers are willing to buy. Surprisingly, the results indicate that increasing buyer expectations may actually encourage buyer innovation. This suggests that, as buyers' expectations increase over time, suppliers are likely to strive to meet this by encouraging buyer innovation. For suppliers this implies that encouraging innovation can be a valuable way to address their customers' increasingly higher 
expectations, thus offering such suppliers an important alternative to competing on price and product only.

\section{Limitations}

Like most other studies focusing on relationships, the focus here is only on the buyer. The supplier's perspective could differ from that of the buyer. For example, when a buyer uses coercive strategies to stimulate the supplier to encourage innovation, the buyer may evaluate the outcome positively, but not the supplier. Another limitation is the reliance on only two items for two of the dark side variables. Without further assumptions, a confirmatory factor analysis using structural equation modeling cannot identify measures when less than three items are available.

Further, the results may not be generalizable to other contexts despite efforts to test the hypotheses in two different industries. Idiosyncrasies in industries and firms may lead to different findings.

Finally, although scholars use the adopted performance measure frequently, the measure relates to a buyer-perceived level of supplier performance and is not an objectively or independently verifiable measure of performance.

\section{Issues for Further Research}

A number of interesting issues for further research arise from this study. Up to now, little research includes relationships' dark side aspects. Consequently, academics and practitioners know little about dark side variables' dynamics and the circumstances under which they occur. Subsequent research may help reveal if, and how, firms attempt to deal with these dark side variables as relationships mature. In addition, this study provides opportunities to identify new 
types of dark side variables within relational, transactional, or contractual exchange. For example, relationship maintenance costs may increase over time.

Another interesting avenue for further research is the degree to which the findings hold in uncertain or turbulent market environments. Dark side variables may play different roles in uncertain or turbulent markets, as innovation is highly important in these contexts. 


\section{References}

Baron Reuben M., Kenny David A. The Moderator-Mediator Variable Distinction in Social Psychological Research: Conceptual, Strategic, and Statistical Considerations. Journal of Personality and Social Psychology 1986; 51 (6): 1173-1182.

Bensaou M., Anderson Erin. Buyer-Supplier Relations in Industrial Markets: When Do Buyers Risk Making Idiosyncratic Investments? Organization Science 1999; 10 (July-August): 460-481.

Bercovitz Janet, Jap Sandy D., Nickerson Jack A. The Antecedents and Performance Implications of Cooperative Exchange Norms. Organization Science 2006; 17 (November-December): 724-740.

Dillman Don A. Mail and Internet Surveys. New York: John Wiley \& Sons, Inc., 2000.

Doyle Peter, Korstjens Marcel, Mitchell Paul. Signals of Vulnerability in Agency-Client Relationships. Journal of Marketing 1980; 44 (Fall): 18-23.

Dwyer F. Robert, Schurr Paul H., Oh Sejo. Developing Buyer-Seller Relationships. Journal of Marketing 1987; 51 (April): 11-27.

Fornell Claes, Larcker David F. Structural Equation Models with Unobservable Variables and Measurement Error: Algebra and Statistics. Journal of Marketing Research 1981; 18 (August): 382-388.

Geyskens Inge, Steenkamp Jan-Benedict. A Meta-analysis of Satisfaction in Marketing Channel Relationships. Journal of Marketing Research 1999; 36 (May): 223-238.

Grayson Kent, Ambler Tim. The Dark Side of Long-Term Relationships in Marketing Services. Journal of Marketing Research 1999; 36 (February): 132-141.

Gruen Thomas W., Summers John O., Acito Frank. Relationship Marketing Activities, Commitment, and Membership Behaviors in Professional Associations. Journal of Marketing 2000; 64 (July): 34-49.

Han Jin K., Kim Namwoon, Srivastava Rajenda K. Market Orientation and Organizational Performance: Is Innovation a Missing Link? Journal of Marketing 1998; 62 (October): $30-45$.

Hauser John, Tellis Gerard J., Griffin Abbie. Research on Innovation: A Review and Agenda for Marketing Science. Marketing Science 2006; 25 (6): 687-717.

Hawkins, Timothy G., Wittmann C. Michael, Beyerlein Michael M. Antecedents and consequences of opportunism in buyer-supplier relations: Research synthesis and new frontiers. Industrial Marketing Management 2008; 37 (8): 895-909.

Heide Jan B., John George. Do Norms Matter in Marketing Relationships? Journal of Marketing 1992; 56 (April): 32-44.

Heide Jan B., Wathne Kenneth H., Rokkan Aksel I. Interfirm Monitoring, Social Contracts, and Relationship Outcomes. Journal of Marketing Research 2007; 44 (August): 425-433.

Hippel Eric von. The Sources of Innovation. New York: Oxford University Press, 1988.

Hurley Robert F., Hult G. Tomas M. Innovation, Market Orientation, and Organizational Learning: An Integration and Empirical Examination. Journal of Marketing 1998; 62 (July): 42-54.

Jap Sandy D., Anderson Erin. Safeguarding Interorganizational Performance and Continuity Under Ex Post Opportunism. Management Science 2003; 49 (12): 1684-1701. 
Jap Sandy D., Ganesan Shankar. Control Mechanisms and the Relationship Life Cycle: Implications for Safeguarding Specific Investments and Developing Commitment. Journal of Marketing Research 2000; 37 (2): 227-245.

Joshi Ashwin W., Arnold Steven. The Impact of Buyer Dependence on Buyer Opportunism in Buyer-Supplier Relationships: The Moderating Role of Relational Norms. Psychology and Marketing 1997; 14 (8): 823-845.

Kumar Nirmalya, Stern Louis W., Achrol Ravi S. Assessing Reseller Performance From the Perspective of the Supplier. Journal of Marketing Research 1992; 29 (May): 238-253.

Kumar Nirmalya, Stern Louis W., Anderson James C. Conducting Interorganizational Research Using Key Informants. Academy of Management Journal 1993; 36 (December): 16331651.

Lusch Robert F., Brown James R. Interdependency. Contracting, and Relational Behavior in Marketing Channels. Journal of Marketing 1996; 60 (October): 19-38.

Mitchell Paul C., Sanders Nicholas H. Loyalty in Agency-Client Relations: The Impact of the Organizational Context. Journal of Advertising Research 1995 (March/April): 9-22.

Moorman Christine, Miner Anne S. The Impact of Organizational Memory on New Product Performance and Creativity. Journal of Marketing Research 1997; 34 (February): 91-106.

Moorman Christine, Zaltman Gerard, Deshpande Rohit. Relationships between Providers and Users of Market Research: The Dynamics of Trust Within and Between Organizations. Journal of Marketing Research 1992; 29 (August): 314-328.

Noordewier Thomas G., John George, Nevin John R. Performance Outcomes of Purchasing Arrangements in Industrial Buyer-Vendor Relationships. Journal of Marketing 1990; 54 (October): 80-93.

Strutton David, Pelton Lou E., Lumpkin James R. The Influence of Psychological Climate on Conflict Resolution Strategies in Franchise Relationships. Journal of the Academy of Marketing Science 1993; 21 (3): 207-215.

Wathne Kenneth H., Heide Jan B. Opportunism in Interfirm Relationships: Forms, Outcomes, and Solutions. Journal of Marketing 2000; 64 (October): 36-51.

Williamson Oliver E. Markets and Hierarchies, Analysis and Antitrust Implications. New York: The Free Press, 1975. 
Table 1: Measurement Scales

\begin{tabular}{|c|c|c|}
\hline Construct & Items & $\begin{array}{l}\text { Cronbach } \\
\text { Alpha }\end{array}$ \\
\hline $\begin{array}{l}\text { Relationship } \\
\text { performance }\end{array}$ & $\begin{array}{l}\text { The association with this supplier has been a highly successful one. } \\
\text { If we had to give a performance appraisal for the past year, it would be very good. } \\
\text { The supplier leaves nothing to be desired from a performance standpoint. } \\
\text { Taking all the different factors into account the supplier's performance has been } \\
\text { excellent. } \\
\text { Generally the results of the relationship with the supplier exceeded our expectations. }\end{array}$ & .90 \\
\hline Innovation & $\begin{array}{l}\text { Our supplier encourages us to find new ways around old problems } \\
\text { Our supplier encourages us to develop own ideas. } \\
\text { Our supplier encourages us to improve upon our methods } \\
\text { Our supplier talks up new ways of doing things. } \\
\text { Our supplier likes us to try new ways of doing things. }\end{array}$ & .86 \\
\hline Flexibility & $\begin{array}{l}\text { Flexibility in response to requests for changes is a characteristic of this relationship. } \\
\text { Changes in terms are not ruled out by both parties if considered necessary. } \\
\text { We expect to make adjustments in the ongoing relationship to cope with changing } \\
\text { circumstances. }\end{array}$ & .71 \\
\hline $\begin{array}{l}\text { Information } \\
\text { exchange }\end{array}$ & $\begin{array}{l}\text { In this relationship, it is expected that any information that might help the other party } \\
\text { will be provided to them. } \\
\text { Exchange of information In this relationship takes place frequently and informally. } \\
\text { It is expected that the parties will provide proprietary information if it can help the } \\
\text { other party. } \\
\text { It is expected that we keep each other informed about events or changes that may } \\
\text { affect the other party. }\end{array}$ & .80 \\
\hline Solidarity & $\begin{array}{l}\text { Problems that arise in the course of this relationship are treated by the parties as joint } \\
\text { rather than individual responsibilities. } \\
\text { The parties are committed to improvements that may benefit the relationship as a } \\
\text { whole and not only the individual parties. } \\
\text { The responsibility for making sure that the relationship works for both of us is a } \\
\text { shared responsibility. }\end{array}$ & .80 \\
\hline $\begin{array}{l}\text { Rising buyer } \\
\text { expectations }\end{array}$ & $\begin{array}{l}\text { The more we work with this supplier, the higher our expectations become. } \\
\text { We hold our supplier to higher standards than we did when we first began working } \\
\text { together. }\end{array}$ & - \\
\hline $\begin{array}{l}\text { Loss of } \\
\text { objectivity }\end{array}$ & $\begin{array}{l}\text { This supplier is able to be objective. (reversed) } \\
\text { It would be useful to work with a new supplier, just to get a fresh perspective. }\end{array}$ & - \\
\hline $\begin{array}{l}\text { Supplier } \\
\text { opportunism }\end{array}$ & $\begin{array}{l}\text { Our supplier makes his work easier by relying on ideas and strategies that have } \\
\text { already been successful with us. } \\
\text { Once our supplier knows what we are looking for they will provide it even if they } \\
\text { know it differs from what they believe is right. } \\
\text { Because this supplier already has a working relationship with us, they think it is all } \\
\text { right to get away with things that would otherwise be unacceptable. }\end{array}$ & formative \\
\hline
\end{tabular}

All scales use seven-point Likert scales ranging from completely disagree to completely agree. 


\section{Table 2: Correlations and Summary Statistics}

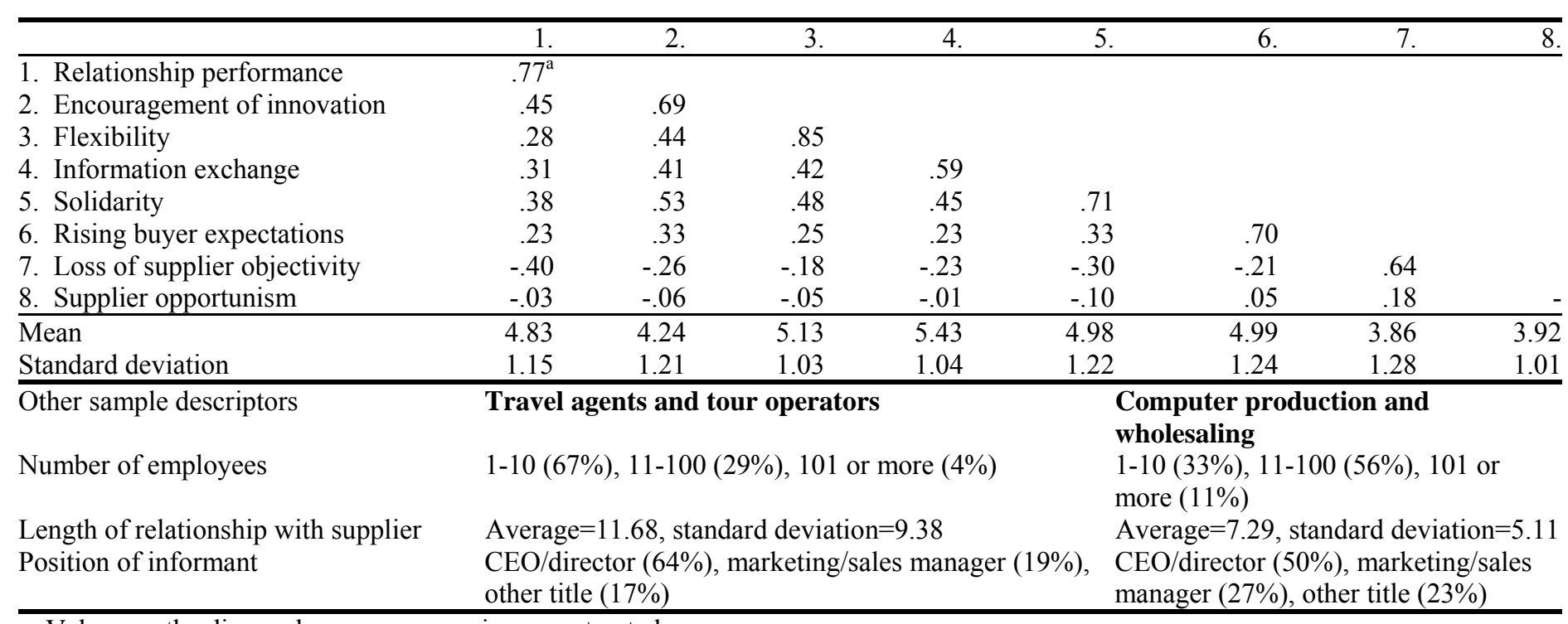

a: Values on the diagonal are average variances extracted. 
Table 3: Results

\begin{tabular}{llrl}
\hline \multicolumn{4}{c}{ Parameter estimates with standard errors in parentheses } \\
Model 1 & Hypothesis and expected sign & \\
\hline Dependent: Innovation $\left(\mathrm{R}^{2}=.37\right)$ & & $.30(.61)$ & \\
Constant & $+(\mathrm{H} 1)$ & $.23(.08)$ & $* * *$ \\
Flexibility & $+(\mathrm{H} 2)$ & $.16(.08)$ & $* *$ \\
Information exchange & $+(\mathrm{H} 3)$ & $.30(.07)$ & $* * *$ \\
Solidarity & $-(\mathrm{H} 4)$ & $.13(.06)$ & $* *$ \\
Rising buyer expectations & $-(\mathrm{H} 5)$ & $-.07(.06)$ & \\
Loss of supplier objectivity & $-(\mathrm{H} 6)$ & $-.01(.07)$ & \\
Supplier opportunism & & & \\
Model 2 & & & \\
\hline Dependent: Relationship performance $\left(\mathrm{R}^{2}=.29\right)$ & $4.09(.49)$ & $* * *$ \\
Constant & & $.34(.06)$ & $* * *$ \\
Innovation & $+(\mathrm{H} 7)$ & $.04(.06)$ & \\
Rising buyer expectations & No hypothesis & & \\
Loss of supplier objectivity & No hypothesis & $-.28(.06)$ & $* * *$ \\
Supplier opportunism & No hypothesis & $.05(.07)$ & \\
\hline$* \mathrm{p}<.10$ & & & \\
$* * \mathrm{p}<.05$ & & & \\
$* * * \mathrm{p}<.01$ & & & \\
Tests are two-tailed, N=207 & &
\end{tabular}


Figure 1: Conceptual Model

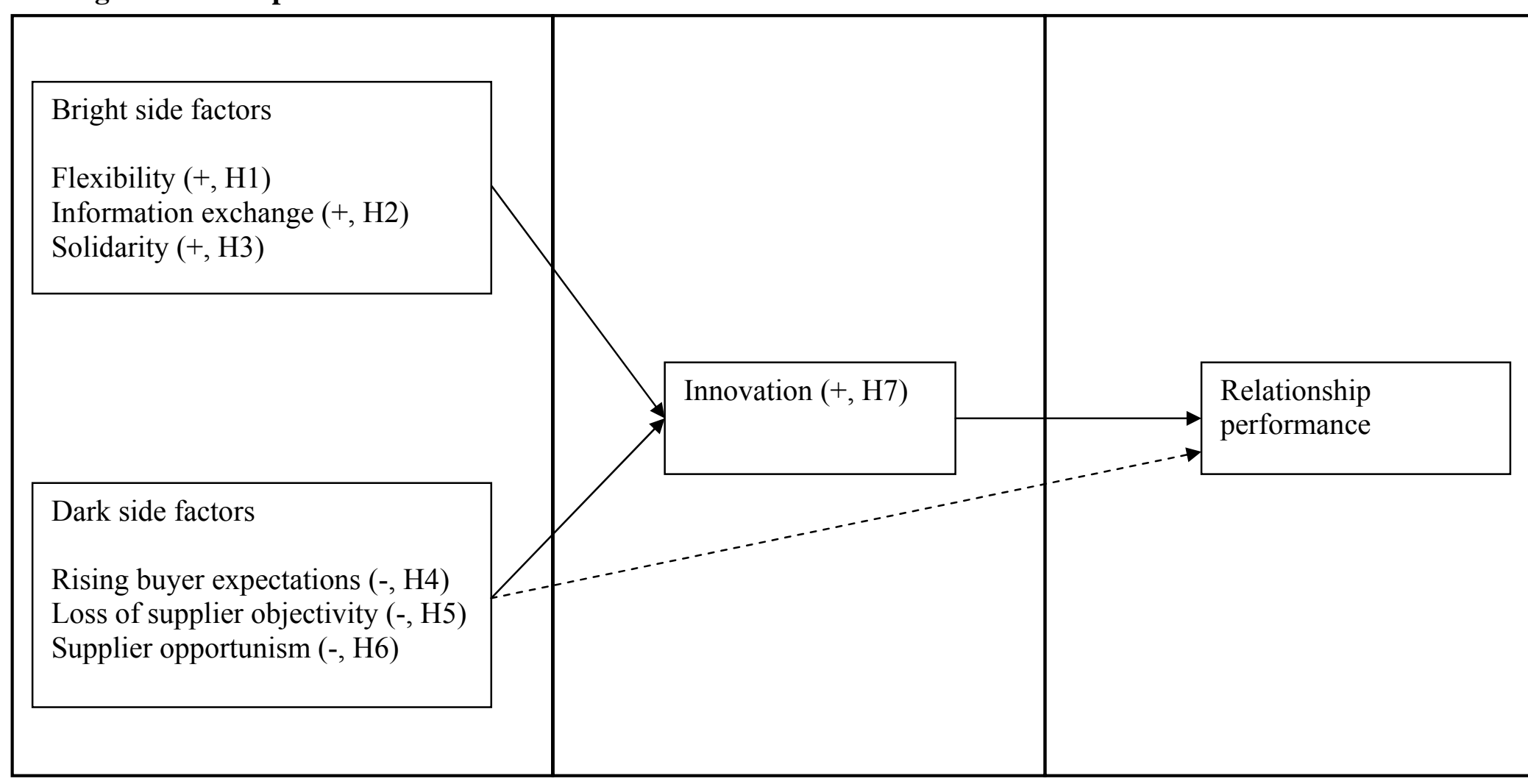

$\longrightarrow$ Hypothesized

- Included but not hypothesized 
